\title{
Brazil: an economy caught in a financial trap (1993-2003)
}

In the early 1990s, Brazil entered a financialized economic dynamic in which short-term financial valorization generated by the issuing of guaranteed public debt overshadowed the entire economy. This article analyzes Brazilian economic processes between 1993 and 2003, in particular the bi-directional relationship with external vulnerability, erratic international financing behavior and how State actions to obtain and maintain these resources fostered financialization. As a result, the entire economy became enmeshed in a self-perpetuating trap in which financial activity was predominant over economic activity.

Keywords: Financialization; financial rent-seeking; public debt; external dependence; financial vulnerability.

JEL Classification: O11; O16.

\section{INTRODUCTION}

With the launching of its "strategy of growth by foreign savings" (Bresser-Pereira, 2003a and 2003b) in the early 1990s, Brazil entered a dynamic of economic development known as financialization: a logic in which short-term financial valorization dominates the rest of the economy, so that the decision-making criteria of the main financial agents and markets takes priority over production activities and defines investment and consumption decisions. This article analyzes the processes that created that dynamic during the 1993-2003 period and seeks to explain the two-way street between financialization and the external vulnerability of the Brazilian economy during those years. The need to attract foreign financing to

\footnotetext{
* Professor of Economic Structure at Universidad de Valladolid. E-mail: bibiana.medialdea@gmail.com. Submitted: 17/January/2012; Approved: 7/August/2012.
} 
cover Brazil's external payment imbalances along with repeated episodes of serious instability due to the potential volatility of capital inflows placed the country in a situation of extremely high external vulnerability. This crucial but erratic financing behavior combined with State actions to capture and maintain resources led to the financialization of economic activity. Consequently, the entire Brazilian economy became enmeshed in a self-perpetuating trap in which financial activity was predominant over economic activity.

\section{FINANCIALIZATION: FINANCIAL LOGIC IMPOSED UPON ECONOMIC DYNAMICS}

Literature on how 'new finances' affect current economic functioning is quite abundant. Beyond a quantitative expansion of financial variables, multiple studies argue that new financial incentives can modify the logic behind the actions of agents and in spheres that were not initially financial. The term financialization ${ }^{1}$ is now used by many authors to refer to the qualitative changes introduced by the logic of new finances.

This article provides an analysis of the process of what is generally understood as financialization, based on the description offered by Epstein (2005, p. 3):

“(...) financialization refers to the growing importance of financial interests, financial markets and financial agents and institutions in the functioning of national and international economies". From this starting point, more specific analytical elements can be implemented to define and quantify the impact of the dominance of finances over other dimensions of economic activity ${ }^{2}$.

The impact of financialization on the entrepreneurial sphere is based on the works of Crotty (2005), Krippner (2005) and Orhangazi (2007), who suggest that, since profits obtainable in the financial sector far exceed those of productive spheres, companies that can enter the financial world will do so to obtain greater returns. This implies a partial re-focusing of the activity of many companies and a re-channeling of resources that would otherwise have been destined for productive investments. Krippner (2005, p. 174) defines financialization as "a pattern of accumulation in which profits accrue primarily through financial channels, rather than

\footnotetext{
${ }^{1}$ Magdoff and Sweezy (1972, pp. 13-16) pioneered the use of this term as it is intended here.

${ }^{2}$ Particularly valuable are the studies that link the various aspects of financialization and offer an outline of how company, family and government behaviors, defined by the logic of financialization, interact and modify overall economic functioning (Bruno, 2005 and 2007; and Stockhammer, 2007).
} 
through trade and commodity production"; which helps to explain why profitability is not directly related to investments in many national economies ${ }^{3}$.

The following section examines the impact of new financial logic on Brazilian families. Most studies in this area focus on the relationship between the financial patrimonialization of households and increased consumption due to the 'wealth effect' created by financial profits, and the greater possibility for indebtedness that accompanies it (Aglietta, 1998 and 2001; Dutt, 2006; and Bhaduri et al., 2006). Such studies are prone to distortions, either because they assume financial profits correspond to the entire population or because they ignore the negative consequences of massive indebtedness. These aspects are especially relevant when analyzing financialization processes in developing countries, where the pattern of profit distribution is such that financial patrimonialization and the ensuing capacity to increase consumption is concentrated within narrow segments of the population.

The crucial role of the State in the economic dynamics of financialization is treated less frequently in the literature. Governmental budgetary activities (income and expenditures) are increasingly dictated by financial markets (Boyer, 1998; and Plihon, 2004), and states are key players in generating the conditions that facilitate and consolidate financialization. This second aspect is generally understood to be implicit and is especially significant in the Brazilian case. Palley (2007, pp. 11-19), rather convincingly suggests that financialization alters economic dynamics by influencing the functioning of financial markets, the behavior of non-financial companies and economic policy. He emphasized the importance of the latter as a state mechanism with important effects on the first two, thereby creating a feedback dynamic with financialization.

\section{GROWTH IN FINANCIAL ASSETS AND INCOMES}

Brazilian financial rent-seeking created spectacular growth in financial assets and income derived from them. Before analyzing the impact of new financial logic on the main economic agents, a brief outline of the extensive growth and current dominance of the financial sector within the Brazilian economy is in order.

The real value of the stock of accumulated financial assets grew rapidly during the 1970s, remained at around $30 \%$ in the 1980s and then almost tripled between 1992 and $2003^{4}$. Such an increase was especially formidable in comparison with the evolution of the productive variables. Graph 1 indicates the relationship betwe-

\footnotetext{
${ }^{3}$ The unprecedented disconnect between profitability and investment dynamics has been analyzed by Husson (2008) for the 'triad', Clévenot and Mazier (2005) for France, Krippner (2005) for the USA and Stockhammer (2007) for Europe.

${ }^{4}$ Following Bruno (2005, p. 350), we estimated existing financial assets by subtracting M1 from M4, which is a reasonable approximation of the wealth obtained on financial markets.
} 
en the value of financial assets and the GDP; which was greater than $45 \%$ between 1999 and 2002, reaching a maximum of $48.6 \%$ in 2001.

Value of financial assets: $1950-2003$

(\% GDP)

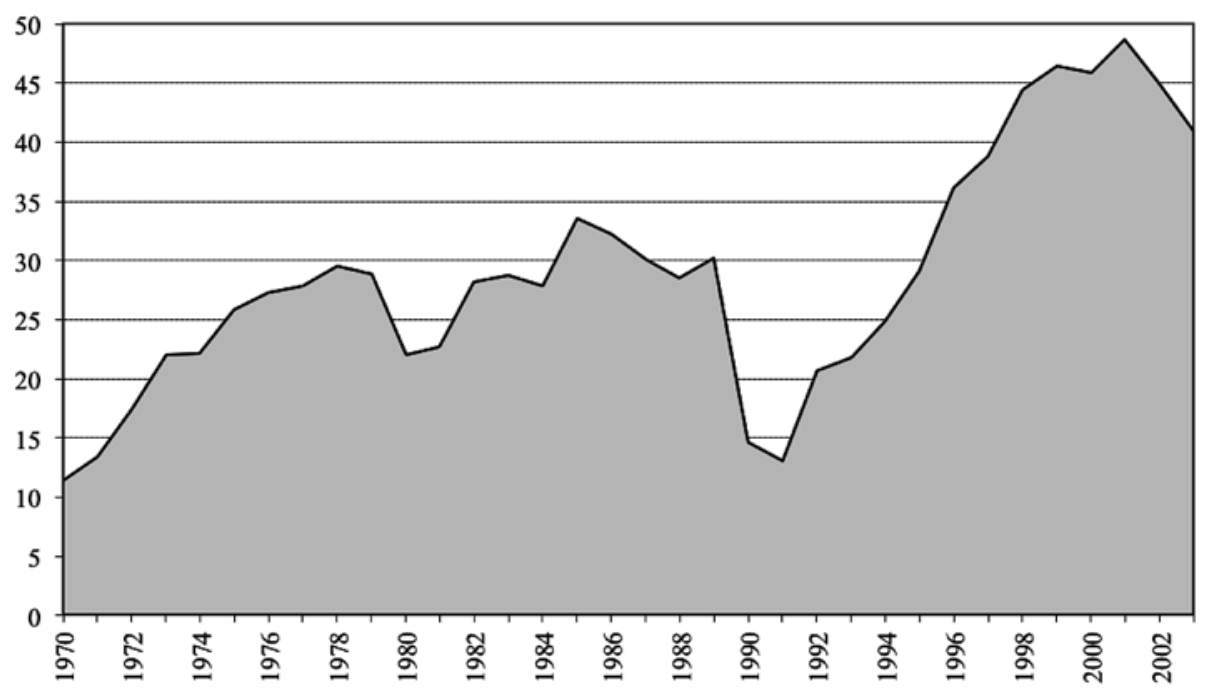

Calculations based on data from BCB (Boletim, Moeda) and IBGE (Sistema de Contas Nacionais), taken as the difference between M4 and M1 over GDP, deflated by the GPI-IA.

Such large assets generate a great deal of income. Not all a country's financial assets are interest-bearing, since financial profit can also derive from the market purchase and sale of stock and from company dividends paid. In the particular case of Brazil, the financial market structure resulted in an overwhelming dominance of public debt, so that most of the financial income was derived from interest paid. The colossal dimensions of interest amounted to $45.9 \%$ of gross disposable income between 1995 and 20035 , indicating that financial rent-seeking had 'hijacked' an excessively high proportion of income. During that time period financial assets and income reached historic heights as a percentage of total production and earnings. However, the effects of finances within the new economic structure were more than quantitative: in this case the financial logic of rent-seeking by investment in indexed guaranteed public debt went beyond the boundaries of normal functioning.

\footnotetext{
${ }^{5}$ Calculations based on data provided by IBGE (Coordenação de Contas Nacionais).
} 


\section{PRODUCTIVE SECTOR COMPANIES UNDER A FINANCIALIZED LOGIC}

Brazilian companies were profoundly impacted in two directions by this contextual change of activity. First, financial rent-seeking enormously complicated access to resources for funding entrepreneurial investment. Second, rent-seeking attracted the capital of important industrial and commercial corporations that were eager to take advantage of guaranteed public debt opportunities.

Between 1994 and 2003, it became much more difficult for the entrepreneurial sector to access bank credit. Credit received by the productive sector as a percent of GDP decreased by $35 \%$, falling from $28 \%$ to $22 \%$ of GDP 6 . In spite of public efforts to compensate the lack of credit offered in the private banking system, most Brazilian companies suffered under severe credit restrictions that were only mitigated for transnational companies (Terra, 2003, pp. 460-463) 7 . As one might expect, problems with accessing credit were especially serious for small and medium-sized enterprises. Research by Morais (2005) indicates that in 1999 only $10 \%$ of small and medium enterprises obtained the bank loans they applied for. A similar figure obtained entrepreneurial financing from friends and relatives.

Additionally, very few companies during these years were able to raise funds by accessing capital markets. According to CMV data, each year only about 10 companies issued negotiable bonds and $3 / 4$ of the total capitalization value was concentrated in a mere $5 \%$ of all the companies listed on the São Paulo stock exchange Bovespa; which is quite a small figure with respect to national GDP. So it is not surprising that self-financing (with all its productive and financial weaknesses) became the main financing mechanism for most companies. During the 1990s, financing by internal resources accounted for as much as $55 \%$ of the financial structure of Brazilian companies (Moreira and Puga, 2000, p. 16).

Parallel to the credit scarcity and insufficient resources from capital markets in Brazilian financial markets, there was a magnificent opportunity for some companies to obtain large, secure and rapid benefits by purchasing indexed guaranteed public debt. Some companies took advantage of this tempting opportunity and the movement of 'productive' companies towards financial rent-seeking became evident on the balance sheets of the 500 largest companies. Between 1996 and 2006, the proportion of 'financial' investments within company assets increased more than $50 \%$, from 6.4 to $10 \%$ (Campelo Jr., 2007, pp. 68-70).

This propensity towards financial rent-seeking in detriment of the primary activity of the company is particularly evident in the largest enterprises, though there is only data for the most recent years. A 2007 study by the consulting firm Economática found that 80 of the 318 largest non-financial corporations in Brazil obtained

\footnotetext{
${ }^{6}$ Based on data from BCB (Boletim, Moeda) and IBGE (Sistema de Contas Nacionais).

${ }^{7}$ Regarding the difficulties of Brazilian companies in finding external financing, see Moreira and Puga (2000), Terra (2003), Morais (2005) and Junqueira and Alves (2007).
} 
over half of their profits from financial markets ${ }^{8}$. Of these 80 companies, 35 registered net financial returns greater than their operational figures. In other words, the main productive activities of these companies had generated losses that were compensated by financial operations. Moreover, the 80 corporations that had obtained the greatest benefits on the financial markets were spread throughout virtually all economic sectors. The largest contingent of the 20 companies with the highest financial profits as a percentage of total profits were found in the commercial sector: food (Lojas Americanas and General Shopping), beverage (Iguaçú Café, Cacique and JBS) and textiles (Vicunha Têxtil, Guararapes, Le Lis Blanc and Cremer). Other prominent groups were in the health (Medial Saúde) and education (SEB) sectors.

The degree of financialization of the 500 largest companies is reflected in the flow of income and payment of interest between 2000 and 2005: the funds destined to the financial system increased by $83.9 \%$ in real terms and the interest earned increased even more, by $126.4 \%{ }^{9}$. The involvement of these 500 companies in financial operations explains the increase in average annual return over net equity from $3.4 \%$ in 1995 to $11.3 \%$ in 2003 , in spite of the fact that they substantially reduced their relative investment expenditures (FGV, 2007, p. 69).

This conclusive empirical evidence shows how entrepreneurial activity, and by extension the investment dynamic, were affected by financial rent-seeking; which is illustrated by comparing the evolution of return rates (defined as the total annual benefits divided by total fixed capital stock in the prior year) with the accumulation rate (expressed as the relationship between investment and that same capital stock). Graph 2 shows that both variables tended to fluctuate in a parallel fashion between 1950 and the early 1990s, but diverged abruptly as the new growth strategy based on external savings became fully operational. This 'disconnect' indicates that in the mid-1990s investment and productive mechanisms stopped corresponding with the rise in the rate of return. Between 1993 and 2003, the rate of return increased some 80\% while private investment grew by only $3.8 \%$ annually. The financial business created around guaranteed public debt in Brazil best explains this disconnect. Increased return rates, fed by rent-seeking, did not stimulate new or more extensive entrepreneurial investment projects; instead they funded greater purchasing of public debt.

Another indicator that can be used to illustrate how financial rent-seeking distorts the productive system is what Bruno (2005 and 2007) refers to as the rate of financialization: the relationship between the real value of accumulated financial assets and the prior year total fixed capital. This compares financial assets with the productive assets of a country. Graph 3 shows how this proportion rapidly increased in the early 1990s from approximately 3\% (due to the Plano Collor freeze on financial assets) to $10-12 \%$ from 1996 on, averaging $11.5 \%$ between 1996 and 2003. The graph also shows how this increase diverged from the symptomatic weakness in the rate of accumulation.

\footnotetext{
${ }^{8}$ The results of this study can be found in the newspaper summary published in O Globo on 19 October, 2008.

${ }^{9}$ Based on data provided by IBGE.
} 
Graph 2

Return and accumulation rates, 1951-2003

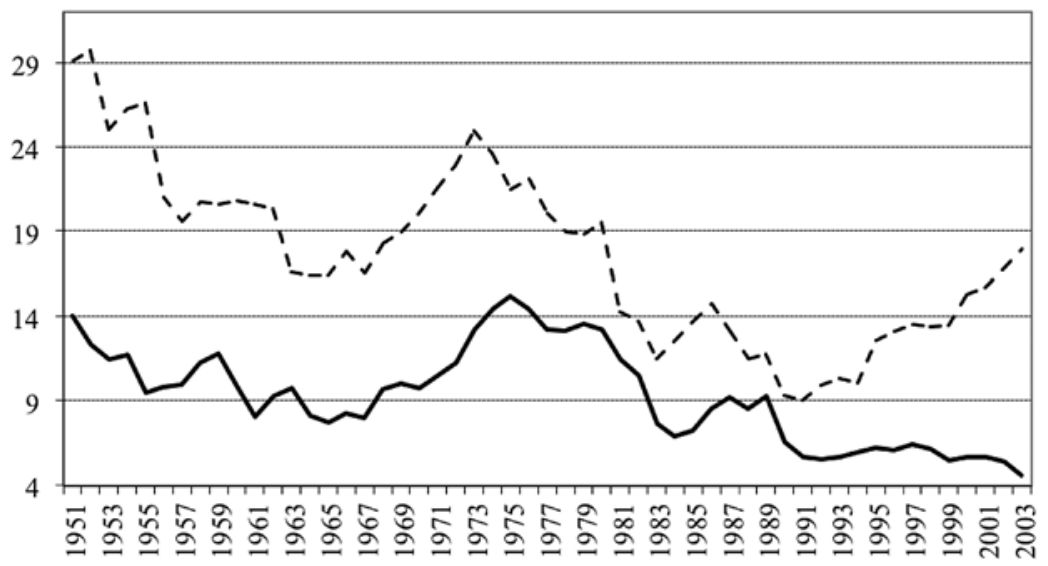

- - - Return rate $\quad$ Accumulation rate

Author's own calculations based on IBGE data (Sistema de Contas Nacionais) regarding investment, and IPEA data for total stock of fixed capital. Overall profits are calculated as the remainder after subtracting salary costs as a percent of GDP.

Graph 3

Accumulation and financialization rates: 1970-2003

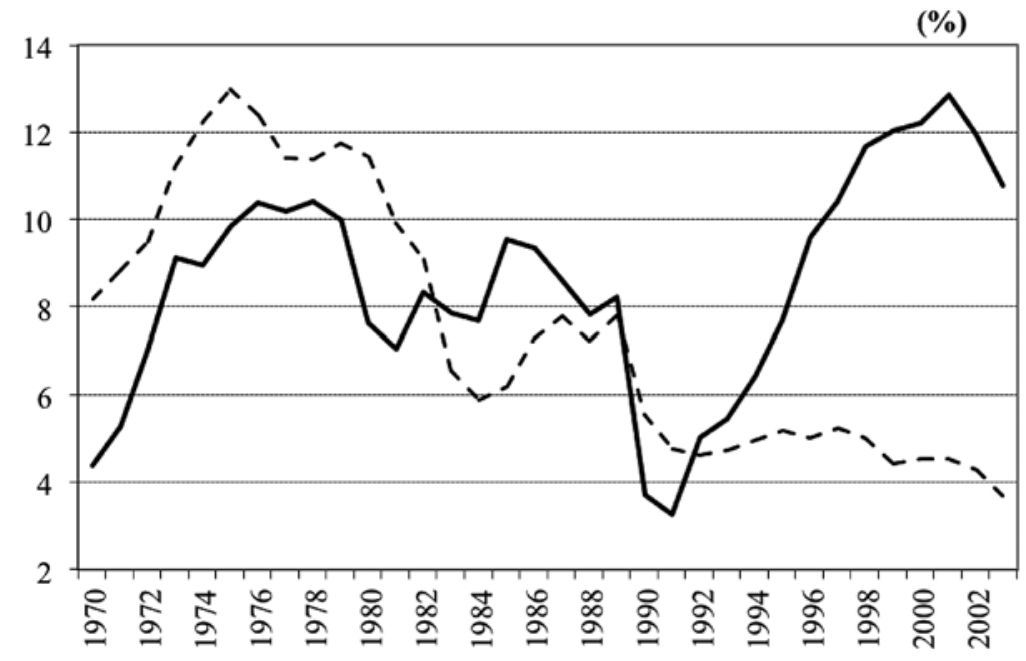

- - Accumulation rate

- Financialization rate

Author's own elaboration based on data from IBGE (Sistema de Contas Nacionais), IPEA and BCB (Boletim, Moeda). The financialization rate is defined as total stock of financial assets (M4-M1) over total prior year fixed capital stock. 


\section{THE MEAGER CONSUMPTION OF MOST FAMILIES IN CONTRAST WITH THE RENT-SEEKING ELITE}

The new economic panorama did not facilitate a general and sustained increase in family consumption. While the expansion of private consumption had helped sustain economic growth between 1993 and 1997, the average annual growth rate was only $0.6 \%$ between 1998 and 2003. Most of the population suffered a deterioration of purchasing power for three main reasons. First, the increase in salaries that began in the early 1990s was short-lived. Average salaries plateaued in 1997 and between 1998 and 2003 decreased at an average annual rate of $-6.7 \%$. In the industrial sector, salaries rose until 1996, and then decreased at an average rate of $6.3 \%$ per year until 2003. As a result, the real value of industrial worker salaries in 2003 was equivalent to what it had been in 1993 . However, minimum wage maintained a slight but positive annual growth rate of $1.1 \%$ during this entire period ${ }^{10}$.

Second, labor market conditions deteriorated considerably during the 1980s and especially during the 1990 s, so that many workers suffered a more intense decrease in income than what is reflected in the data regarding average salaries. The effects were particularly negative on informal workers and the unemployed ${ }^{11}$. Although the indicators used to measure unemployment rates can give very different scenarios ${ }^{12}$, they all confirm a significant increase in unemployment among the active population. Between 1990 and 2003 the open unemployment rate published by IBGE (Pesquisa Mensal de Emprego) grew from 7.2\% to $12.3 \%$. Total unemployment (including 'hidden unemployment due to job insecurity' and 'hidden unemployment due to discouragement') estimated by the Seade-Dieese foundation (Pesquisa de Emprego e Desemprego) for the São Paulo metropolitan area rose from $10 \%$ to $19.9 \%$. The OIT (2007) calculated that urban unemployment had increased from $4.3 \%$ to $12.3 \%$.

This situation was accompanied by a fairly large increase in workers whose labor status did not completely reflect their salaried condition. Informal workers included those classified in the statistics as 'undocumented' or 'self-employed'; most of whom were 'involuntarily self-employed' according to several empirical studies (Malaguti, 2001). The proportion of informal to total workers increased from $40.9 \%$ to $50 \%$ between 1990 and $2001^{13}$. Such a large number of workers excluded from any labor regulation indicates that much of the active population received

\footnotetext{
${ }^{10}$ Data based on the findings of Seade-Dieese (Pesquisa de Emprego) for average salary, on IPEA for minimum wage and Fiesp for industrial salaries, deflated by the NCPI. Average salary refers to the main wage income of the individual. This and the industrial wage figure refer only to the São Paulo metropolitan area.

${ }^{11}$ On job instability, see: Mattoso (1999), Cardoso (2001), Antunes and Silva (2004) and Medialdea (2009).

${ }^{12}$ A discussion of the methodological differences in the various estimates of unemployment rates in Brazil can be found in Celso Jr. (2001).

${ }^{13}$ Informal unemployment rate calculated using data from IBGE (Pesquisa Mensal de Emprego). Methodological changes have made it impossible to construct a homogeneous series through 2003.
} 
income below statistical averages. According to IBGE data, 'undocumented' workers were paid $35.2 \%$ less than legal workers and 'self-employed' workers received an average of $26 \%$ less than legal salaried workers ${ }^{14}$.

Third, most families could not access bank loans, which meant that their purchasing power did not extend much beyond their weakened income. Although personal credit did increase between 1994 and 2003, its influence on consumption was quite small (Junqueira and Alves, 2007). Probably to compensate for shrinking salaries, family indebtedness increased but was not related to any significant rise in sales, as Graph 4 illustrates. From mid-1994 through the end of 2003, family indebtedness actually increased five-fold in real terms, but sales of consumption goods only increased $15 \%$. Using May, 1994 as a baseline index of 100, in 2003 average personal credit rose to 512.4 , sales were 115.6 and salaries had fallen to 67.9.

Graph 4

Wages, personal credit and familiar consumption: 1994-2003

(baseline value of 100 set for May, 1994)

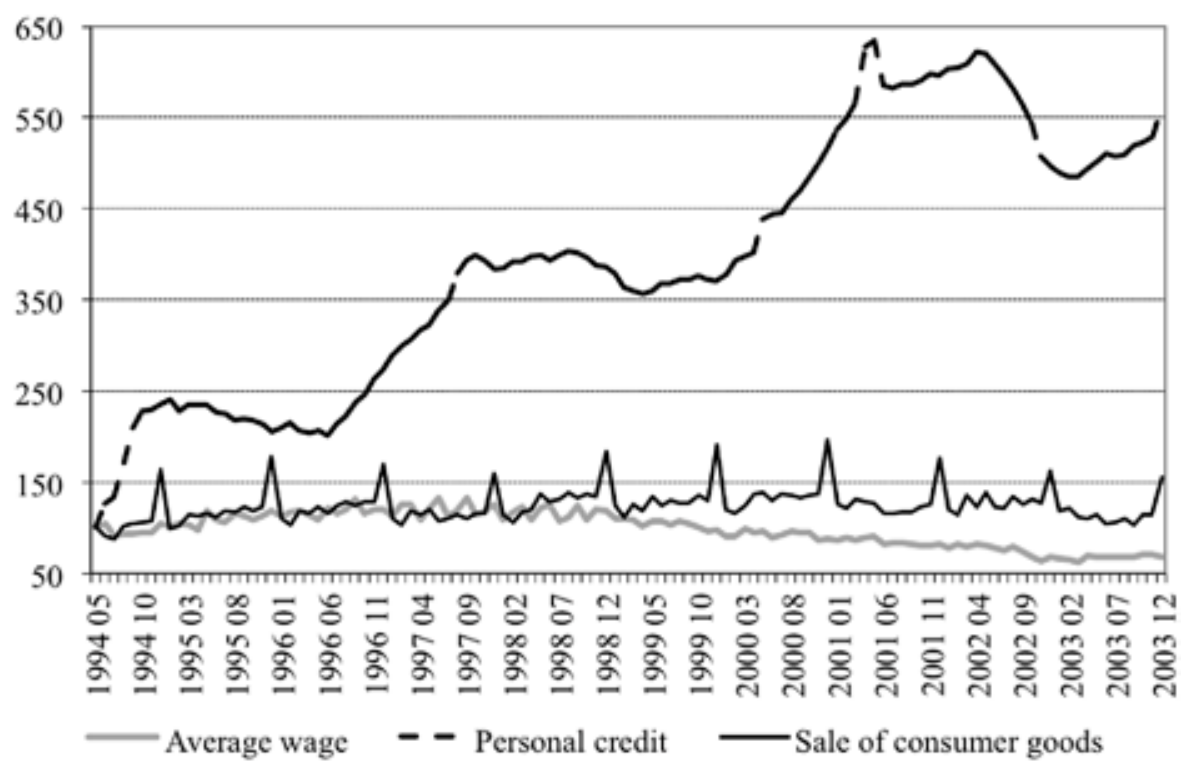

Author's own elaboration, based on data from Seade-Dieese (Pesquisa de Emprego e Desemprego) for the average salary, BCB (Boletim, Moeda) for personal credit and Fedecomercio (taken from IPEA) for sales. Data deflated by GPI-IA. The horizontal axis indicates years and months.

A dual pattern in Brazilian consumption became more evident during this period. While deteriorating incomes restricted purchasing power for most of socie-

\footnotetext{
${ }^{14}$ Averages for 1991 and 2003 based on IBGE data (Pesquisa Mensal de Emprego). Only metropolitan areas are included.
} 
ty, a thin upper layer of society could continue increasing its consumption and financial income thanks to its double link to the financial system. This group had both access to credit and the means to acquire high-interest guaranteed securities on the public debt market. Though this mechanism did stimulate growth of private consumption, it only affected the upper-middle and upper classes; so its impact on aggregate consumption growth for the entire population was quite limited.

\section{THE STATE TRAPPED IN FINANCIALIZATION}

The Brazilian government, through its economic policy and institutional reforms associated with the 'strategy of growth by external savings' laid the groundwork for financialization and was in turn its main victim. The new context severely restricted the State's room to maneuver and forced it to produce the conditions demanded by the financial markets; so the State itself was trapped in the logic of financialization.

With the new growth strategy, the Brazilian government engaged in activities that required a very significant volume of financing. The bank restructuring process involved a fiscal cost of around $11 \%$ of the GDP, based on the calculations of Sáinz and Calcagno (1999, pp. 26-27) $)^{15}$. However, the strategy did not include elements that would create an equivalent increase in State revenues. Although there were important revenues from privatization (38.1 billion US dollars from 1994-97 according to BNDES, 2002); the capacity for taxation remained limited. Consequently, primary surpluses disappeared after 1994 and the State began to experience significant negative operational balances due to huge financial expenditures. The State went from a surplus equivalent to $1.6 \%$ of GDP in 1994 to an average deficit of 4.2\% of GDP between 1995 and 1997 (BCB, Boletim, Finanças Públicas).

Fiscal deterioration began to accelerate in 1998. Deficits of prior years had been financed by public debt securities and total public indebtedness had begun to increase in 1997. Simultaneously, interest rates rose rapidly and substantially increased additional issues of indexed securities. The subsequent sharp increase in financing costs in 1998 caused an extreme fiscal deficit of 7.4\% of the GDP. When the long-delayed fiscal adjustment was implemented in 1999, the financial situation of the State was already critical.

From this time on, achieving a primary surplus became the central goal of fiscal policy. Even Presidential candidate Luiz Inácio Lula da Silva, who represented a possible change in the direction of national economic policy, publicly committed to achieving primary surpluses during his October, 2002 electoral campaign: "We will maintain the primary surplus policy as long as necessary to avoid an increase

\footnotetext{
${ }^{15}$ Based on the 1998 GDP and including costs of capitalization for the Banco de Brasil, the PROER, the PROES, and other state bank intervention mechanisms, as well as the restructuring of agricultural debt.
} 
in internal debt and destruction of trust in the government's capacity to honor its commitments" ${ }^{16}$. From 1999 on, Brazil began to show significant primary surpluses that grew from year to year, over and above the objectives of the International Monetary Fund agreements. Between 1999 and 2003, the average surplus was 3.5\% of GDP. During this period, the State generated a 'savings' of approximately 20 billion US dollars per year ${ }^{17}$. However, achieving such large primary surpluses meant living with increasing financial burdens: the average financial deficit was $4.8 \%$ for the 1999-2003 period. Every year the State allotted some 27.5 billion US dollars to the repayment of public debt securities. The resources saved by cutting back on current account expenditures were insufficient to cover the financial obligations and new operating deficits arose that required new financing.

The State was again entering a Ponzi-type spiral similar to what it had experienced in the 1980s. The funds that banks, other financial agents, productive sector companies and certain families dedicated to purchasing public debt securities were diverted from reactivating national productive activity. From 1998 to 2003, while annual consumption grew slowly at $0.9 \%$, the State seriously reduced its investments (by $10.7 \%$ annually) as it dedicated a considerable proportion of its limited revenues to paying interest ${ }^{18}$.

The revenues obtained from the sale of public debt securities were dedicated in large part to paying the interest on prior State debt, but the State knew it would also have to return the principal at some point. Investors in public debt increased their returns and perpetuated a rent-seeking behavior while the State increased its financial payments and perpetuated a debtor behavior. The national debt rapidly increased from $30.1 \%$ of GDP in 1996 to $57.3 \%$ in $2002^{19}$. Though it had already reduced its non-financial expenditures in order to pay interests and thereby sacrificed its capacity to influence the economy through investment and re-distribution, the government was unable to break out of this spiral. It had created the conditions for financialization and had become trapped in its effects.

\section{EXTERNAL DEPENDENCE AND FINANCIAL VULNERABILITY}

The Ponzi-like dynamics at work in public accounts also affected external accounts. The effort to attract significant external savings led to rapid deterioration in the external sector. Moderate annual deficits or even the small surplus recorded

\footnotetext{
${ }^{16}$ Carta ao Povo Brasileiro, which the Partidos dos Trabalhadores (PT) made public just before election day. See: http://www.iisg.nl/collections/carta_ao_povo_brasileiro.pdf

${ }^{17}$ Average for 1999-2003. Author's own calculations based on GDP in US dollars, estimated by the BCB.

${ }^{18}$ Author's own elaboration based on IBGE (Sistema de Contas Nacionais) and IPEA data.

${ }^{19}$ Author's own elaboration based on data from BCB (Boletim, Finanças Pública) and IBGE (Sistema de Contas Nacionais).
} 
in 1992 were a thing of the past by 1995, and had reached 3\% of GDP by $1997^{20}$. This deficit was largely fed by the expenses associated with international financing. Until 1995, the net outflows of returns on investment amounted to approximately 10 billion US dollars per year; by 1997 they had increased to 15 billion US dollars annually. Foreign capital invested cost Brazil $1.8 \%$ of its GDP on average between 1993 and 1997. Between 1998 and 2003, Brazil required international financing equivalent on average to $3.1 \%$ of GDP (approximately 18.275 billion US dollars annually). This increasing external vulnerability was further accentuated by the increasing volatility of financial resources flowing into Brazil.

Greater volatility was caused by the variable behavior of portfolio investment flows. Using the relationship between gross capital inflows and net capital attracted to measure volatility, Graph 5 shows how foreign portfolio investments, though always fairly erratic, increased in volatility. For most quarters from 1990 to 1993 , gross inflows were approximately $150 \%$ of net funds captured, so that capital outflow was equivalent to one third of inflow. From 1994 to 1997, volatility grew to approximately $300 \%$ for most quarters. In net figures only one of every three dollars entering the country was captured; the other two dollars exited the country. The volatility index went from $-136 \%$ in 1995 Q1 (with the effects of the Mexican crisis) to $-287 \%$ in 1997 Q4 (after the Southeast Asian crisis).

In 1998 volatility began to radically intensify and the turnover of resources entering and exiting the country reached colossal proportions. In 1999 Q3, net portfolio investments amounted to $2,450 \%$ of net captured income. In other words, for every 245 dollars that entered, only one remained at the end of a given quarter. At the close of 2002, volatility again became very intense, reaching $1,650 \%$. Such high volatility was sometimes associated with negative net captured funds: in 1998 Q3 (with the impact of the Russian moratorium), volatility reached - 180\%; during 1999 Q1 (after devaluation of the Brazilian currency), volatility was at $93 \%$; in 2001 Q2 volatility was at $-1,085 \%$ and in 2001 Q4 it was at $-145 \%$. The 2002 election year was particularly turbulent, with high negative volatility rates in three of the four quarters. Finally, in 2003 Q3 foreign portfolio investment outflows were again well above inflows, with volatility at an astounding $-1,980 \%$.

This highly unstable behavior explains why foreign capital exerted such a significant influence on the economic processes at work in Brazil, in spite of reduced net foreign capital from 1998 on. Although international investors decreased their participation in the portfolio of assets traded on Bovespa, which went from $15 \%$ in mid-1997 to $8-9 \%$ in 2000-2003 (based on CVM data), participation in the total volume of stock exchange trading (measured as the sum of purchases and sales) remained relatively stable at a fairly high level of $50 \%$ during the entire period.

Graph 6 confirms that foreign capital activity determined the level of the Brazilian stock market, as indicated by the evolution of its reference index. Ibovespa

\footnotetext{
${ }^{20}$ Unless otherwise indicated, the data in this section are compiled from the BCB (Boletim, Balanço de Pagamentos) and BCB estimates of the GDP in US dollars.
} 


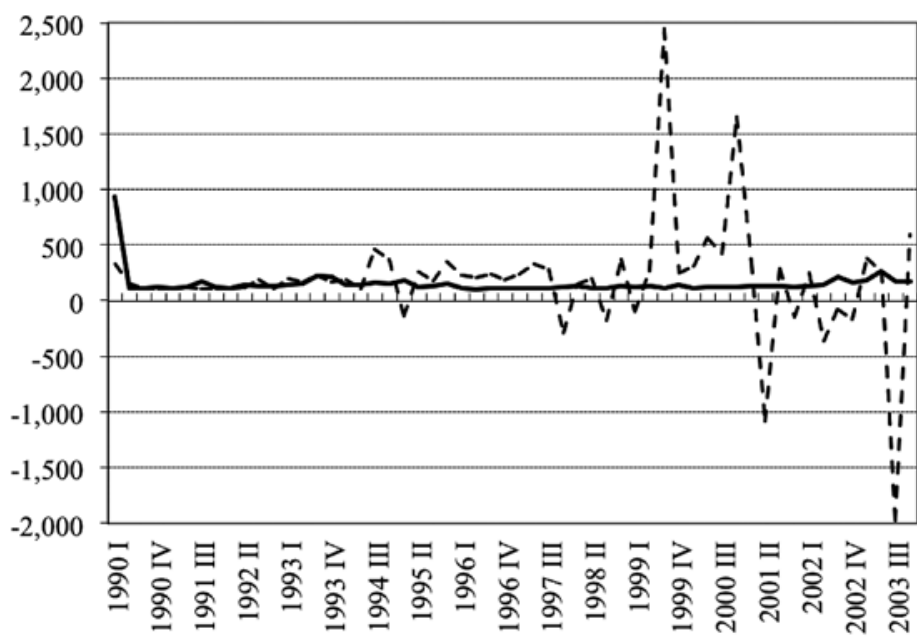

- - - Foreign portfolio investment -Foreign direct investment

Author's own elaboration based on data from BCB (Boletim, Balanço de Pagamentos). The horizontal axis indicates years and quarters (Roman numerals).

\section{Graph 6}

Foreign capital and Ibovespa index: 1995-2003

(in millions of US dollars and basic points)

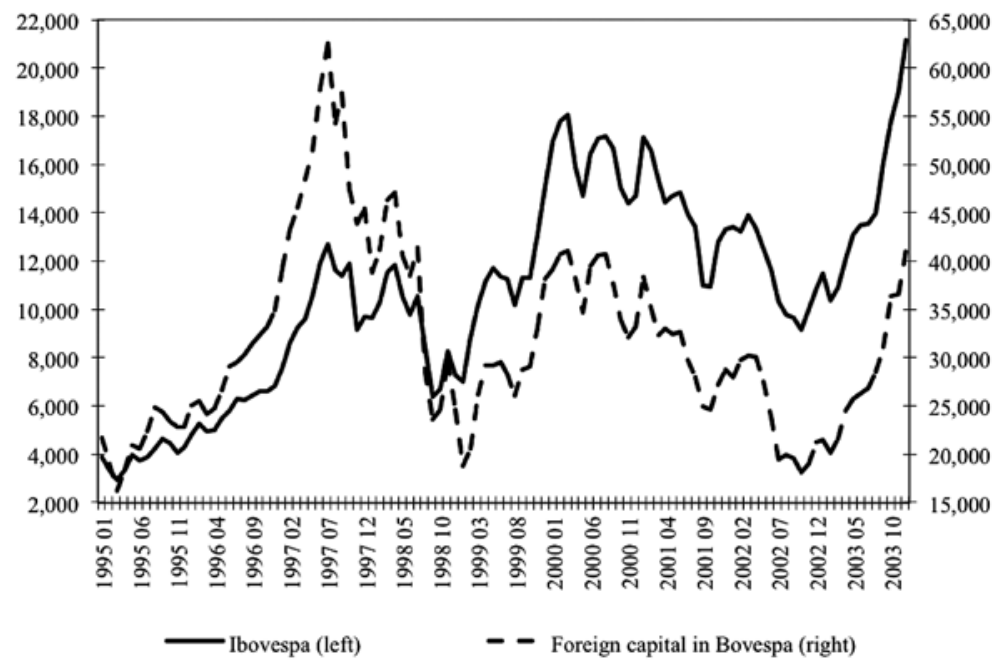

Bovespa data taken from CVM, available in the Gazeta Mercantil (IPEA). The horizontal axis indicates years and months. 
recorded a first maximum of 12,212 points in mid-1997, at a time when foreign investor trading of Brazilian financial assets was at its peak. In the 1998 'Black September', foreign capital suddenly reduced its presence in the stock market and Ibovespa fell dramatically to 6,389 points. Stock exchanges by foreign investors again fell in September, 2001 and the Ibovespa market index declined 18\% from one month to the next. In the period prior to the October, 2002 elections, the index fell again below 10,000 points. The influence of foreign capital on the dynamics of the Brazilian economy was decisive during these years.

\section{THE VICIOUS CIRCLE OF FINANCIALIZATION}

Although net foreign investment in Brazil decreased significantly between late 1998 and 2003, it retained an important role in absolute terms and remained central to economic functioning. The interaction between international capital and the State created a vicious circle: while foreign capital was essential to the Brazilian economy, it reinforced Brazilian vulnerability internationally. Every time international investors reacted to an event by imposing stricter conditions for investing or remaining in Brazil, threatening to divest or reduce financial inflows, the State intensified its mechanisms to attract investors.

Such scenarios occurred repeatedly after the Asian crisis of 1997. The following year, Russia declared a moratorium on its payments, and a few months later the exchange rate parity for the Brazilian currency was completely lost. The relative stability in 2000 was interrupted by the New York Stock Exchange and NASDAQ crash. In mid-2001, the Brazilian energy sector went into crisis, followed by the international market shockwaves that emanated from the September 11 terrorist attacks on the USA. In 2002 Q4, further instability was created by survey projections suggesting that the upcoming Brazilian elections would be won by the Partido dos Trabalhadores.

The attitude of foreign investors towards Brazilian financial assets was heavily influenced by these events, even in the absence of any direct link between the assets and the events. In spite of their high returns, Brazilian assets were clearly considered risky. Graph 7 shows the sudden and dramatic increases in country risk and the events that fed this dynamic through 2003. Each new event significantly reduced the inflow of foreign portfolio investments and accelerated disinvestment, diminishing the level of international reserves and increasing Brazil's country risk.

These events led the State to increase its measures to counteract the growing distrust of foreign capital towards Brazilian financial assets. After selling the large State companies, two main measures remained: to raise the interest rates and/or increase the issue of public debt indexed to the interest rates.

The following two graphs show how those mechanisms were activated virtually every time foreign capital threatened to exit the country (ANDIMA, 1995-2007). The Selic rate increased from $22 \%$ to $43.3 \%$ between October and November of 1997 , followed by a $58.5 \%$ increase in the real value of the public debt securities from November to December. One year later, the Russian moratorium was com- 


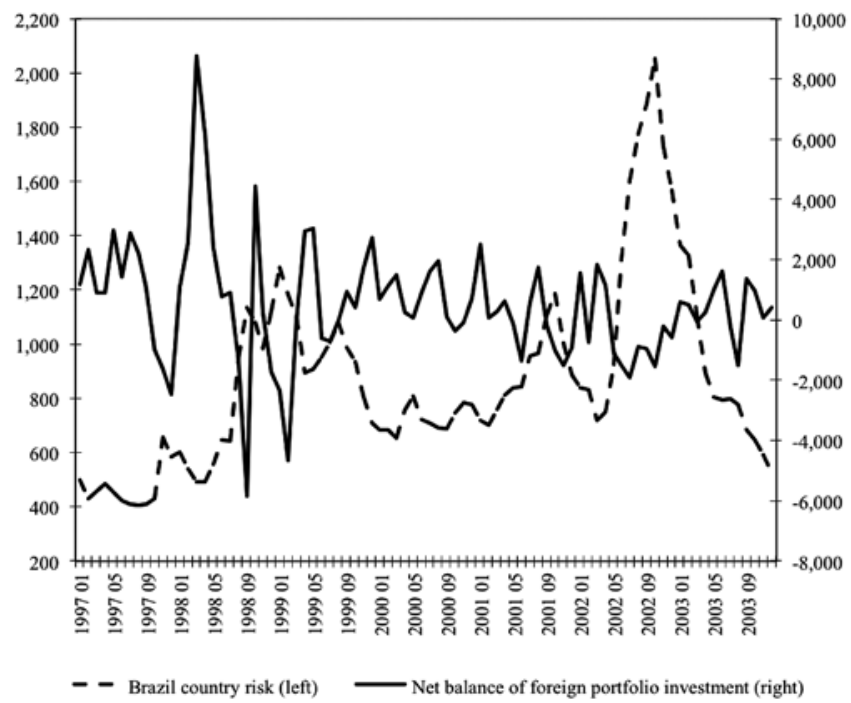

Data from Valor Econômico (IPEA) for Brazil country risk and from BCB (Boletim, Balanço de Pagamentos) for foreign investment. Brazil country risk is expressed as the difference in basic points between US Treasury Bonds and Brazilian $C$-bonds. The horizontal axis indicates years and months.

pensated for by issuing more securities indexed to the Selic rate (LFT) and the exchange rate (increased issue of NBC-E and creation of NBC-F); and the issue of guaranteed public securities rose to $66 \%$ of all public debt issued. Furthermore, banks were allowed to purchase exchange rate linked securities using resources that had until then been restricted to agricultural purposes, and foreign investment in fixed return funds was exempted from taxation. Unfortunately, these measures were insufficient and, in an attempt to stop capital flight, the Selic rate again rose dramatically (from $19.2 \%$ to $41.6 \%$ between August and October of 1998). The Brazilian real was soon devaluated and again the interest rate rose from $29.5 \%$ to $48.2 \%$ between January and March of 1999 . The amount of public debt securities issued between January and May increased $12 \%$, including a $28 \%$ rise in indexed securities with respect to the prior year.

The financial turbulence of 2001 again activated the same mechanism: the Selic rate increased from $12.9 \%$ in February to $20.1 \%$ in October. Graph 8 shows how the total volume of public debt securities issued began to decrease in mid-2002, when exchange rate linked securities began to be retired ${ }^{21}$. Interest rate adjustments

\footnotetext{
${ }^{21}$ It is important to note that the State re-purchased securities corrected to the exchange rate when the Brazilian real was weakening against the dollar, which benefitted private investors (Carvalho, 2007, p. 104-105).
} 
were used to compensate for the uncertainty caused by the October, 2002 elections. The Comitê de Politica Monetária (Copom) raised the Selic rate from $17.9 \%$ to $21.6 \%$ between September and October of 2002. After the elections, ongoing market concern regarding what policies the new government would adopt caused the interest rates to rise to $26.4 \%$ by January, 2003. The issuing of public debt securities also increased 14.9\% between December, 2002 and July, 2003.

Graph 8

Public debt securities issued and Selic rate: 1997-1999 (figured indexed to a January 1997 base of 100 and \% annual rate)

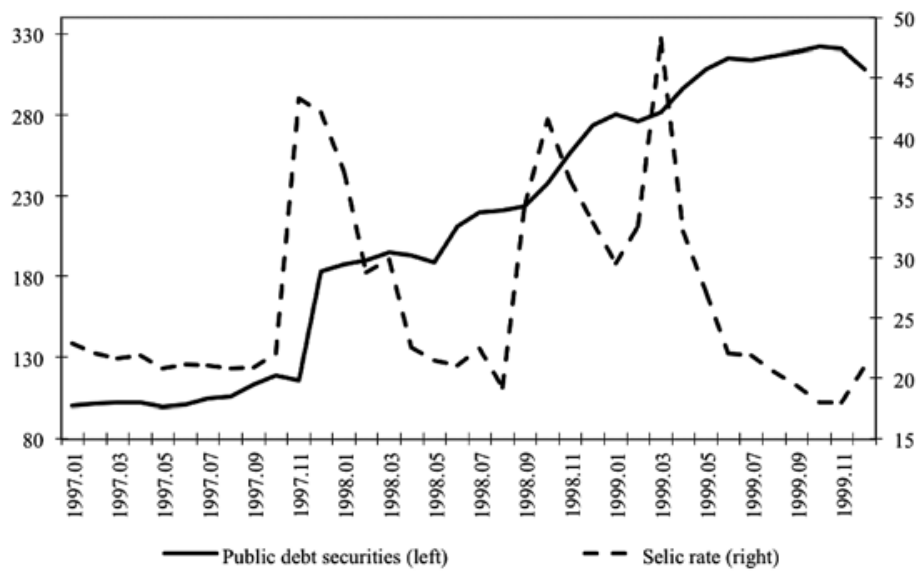

Graph 9

Public debt securities and Selic rate: 2000-2003 (figured indexed to a January 2000 base of 100 and \% annual rate)

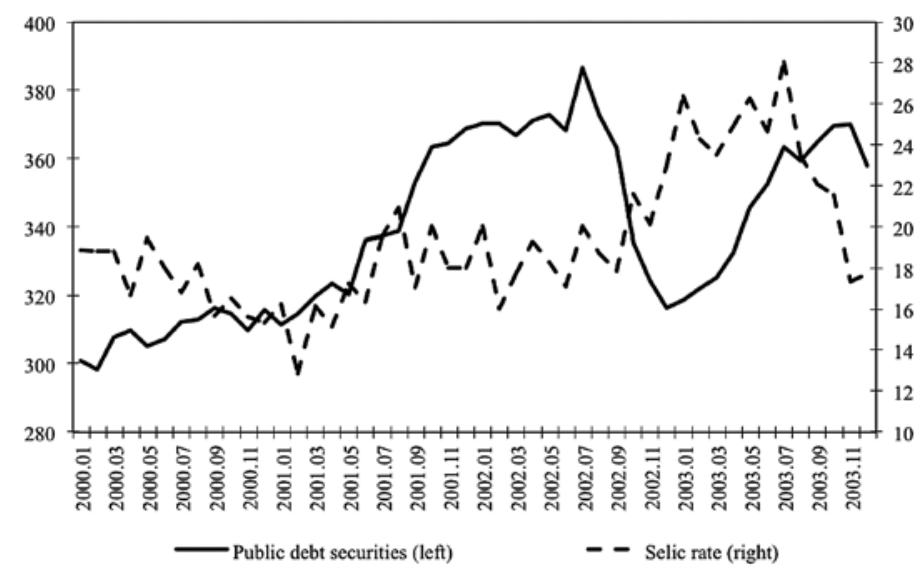

Author's own elaboration using data from BCB (Boletim, Finanças Públicas) for public debt securities issued and from BCB (Boletim, Mercado Financeiro e de Capitais) for Selic rate. Public debt securities included are LFT, LTN, BTN, NTN and CTN/CFT. The securities issued were deflated by the GPI-IA. The horizontal axis indicates years and months. 
Throughout this period the need for foreign capital investment, combined with a foreign capital preference for public debt securities indexed to interest rates, functioned to create a self-perpetuating dynamic with the State mechanisms implemented to retain the foreign capital needed for financing.

\section{CONCLUSION: A FINANCIAL TRAP}

While seeking to counteract threats of foreign capital exit, interest rate increases and greater issuing of indexed public debt securities deepened the financialization of the Brazilian economy. Interest rate hikes also increased the profitability of investing in Brazilian debt, which was mostly linked to the daily interest rate (LFT). This reinforced the propensity of all agents - foreign capital, banks and other financial agents, non-financial companies and upper-middle to high income families - towards rent-seeking by means of guaranteed debt. As financial intermediaries channeled greater resources into the financial sphere, fewer resources were available for productive investment in companies and consumption by the majority of families. Simultaneously, greater returns from public debt securities increased State financial costs, which forced the State to issue increasing amounts of debt in order to finance prior obligations. The interaction with foreign rent-seeking capital fed the fiscal deficit, which in turn fed the demand for foreign resources needed for the entire Brazilian economy.

Based on its strategy to capture external savings, the State provided favorable conditions for attracting international capital, which mostly sought value over a short investment period. Short-term financial returns on investment enticed both foreign capital and other significant national Brazilian actors, including financial agents (banks and investment funds), large industrial companies and the upper strata of society. Economic activity thus became financialized.

Soon, the pressing need for external resources, in conjunction with the high potential volatility of foreign financial investments in Brazil during this period forced the economy into a state of permanent vulnerability to the behavior of foreign investors. Successive episodes of uncertainty and instability were generated by erratic foreign investment behavior, and the State could only contain the exit of foreign capital by applying measures that intensified financialization. This self-perpetuating dynamic, which functioned as a trap, had extremely detrimental effects on the Brazilian economy.

\section{REFERENCES}

AGLIETTA, Michel (1998) Le capitalisme de demain. Paris: Notes de la Fondation Saint-Simon, 101. AGLIETTA, Michel (2001) Macroeconomie financiere, Finance, croissance et cycles (volumen I), and Macroeconomie financiere, Crises financieres et regulation monetaire (volumen II). Paris: La Decouverte. 
AGLIETTA, Michel and REBERIOUX, Antoine (2004) Derives du capitalisme financier. Paris: Albin Michel.

ANDIMA (1995-2007) Retrospectiva(1994-2006). Rio de Janeiro: ANDIMA.

ANTUNES, Ricardo and SILVA, Maria A. de M. (2004) O Avesso do Trabalho. São Paulo: Expressão Popular.

BHADURI, Amit, LASKI, Kazimierz and RIESE, Martin (2006) "A model of interaction between the virtual and the real economy". Metroeconomica, 1(57): 412-427.

BNDES (2002) Privatização no Brasil: 1990-94 / 1995-2002. Rio de Janeiro: BNDES.

BOYER, Robert (1998) Le politique a l'ere de la mondialisation et de la finance: le point sur quelques recherches regulationnistes. Paris: CEPREMAP.

BRESSER-PEREIRA, Luiz C. (2003a) “Brazil's Quasi-Stagnation and the Growth cum Foreing Saving Strategy". International Journal of Political Economy, 32(4): 76-102.

BRESSER-PEREIRA, Luiz C. (2003b) “O Segundo Consenso de Washington e a Quase Estagnação da Economia Brasileira”. Revista de Economia Política, 23(3): 3-33.

BRUNO, Miguel (2005) Croissance Économique, Changements Estructurales et Distribution: les transformation du régime d'accumulation au Brésil - une analyse régulationnista. Paris/Rio de Janeiro: Doctoral Thesis, EHESS-IE/UFRJ.

BRUNO, Miguel (2007) "Financiaritasion et Accumulation du Capital Productif au Brésil”. Revue Tiers Monde, 189: 65-92.

CAMPELO Jr., Aloisio (2007) “Uma Rentabilidade Recorde”. Conjuntura Econômica, 6(8): 68-70.

CARDOSO Jr., Jose Celso (2001) Crise e Desregulação do Trabalho no Brasil. IPEA. Texto para Discussão num. 814.

CARVALHO, Carlos E. (2007) "Dívida Pública: politizar o problema para derrotar a dominção dos credores”, in Sicsú, João (Org): Arrecadação (de onde vem) e Gastos Públicos (para onde vão?). São Paulo: Boitempo.

CELSO Jr., José (2001) Crise e Desregulação do Trabalho no Brasil. IPEA. Texto para Discussão num. 814.

CLÉVENOR, Mickaël and MAZIER, Jacques (2005) Investment and rate of profit in a financial context: The French case. University Paris-Nord, UMR num. 7115.

CROTTY, James (2005) "The Neoliberal Paradox: the impact of destructive product market competition and $<<$ modern $>>$ financial markets on nonfinancial corporation performance in the neoliberal era", in Epstein, Gerald A. (Ed.): Financialization and the World Economy. Cheltenham: Edward Elgar.

DUTT, Amitava K. (2006) “Maturity, stagnation and consumer debt: a Stendlian approach". Metroeconomica, 57: 339-364.

EPSTEIN, Gerald A. (Ed.) (2005) Financialization and the World Economy. Cheltenham: Edward Elgar.

Fundação Getulio Vargas (FGV) (2007) Conjuntura Econômica, 61(8).

HUSSON, Michel (2008) Le capitalisme toxique. Paris: IRES.

JUNQUEIRA, Juliano A. and ALVES, Luciana S. (2007) "Restrições de Crédito e Decisões Intrafamiliares”. Revista Brasileira de Economia, 6(2): 201-229.

KRIPPNER, Greta R. (2005) "The Financialization of the American economy". Socio-Economic Review, 3(2): 173-208.

MAGDOFF, Harry and SWEEZY, Paul M. (1972) The Dynamics of US Capitalism. New York: Monthly Review Press.

MALAGUTI, Manoel L. (2001) Crítica a Razão Informal: a Imaterialidade do Asalariado. São Paulo: Boitempo.

MATTOSO, Jorge (1999) O Brasil Desempregado. São Paulo: Fundação Perseu Abramo.

MEDIALDEA, Bibiana (2009) “Ajuste salarial en Brasil: 1994-2007”, in Álvarez Peralta et al.: Ajuste y Salario. Las consecuencias del neoliberalismo en América Latina y Estados Unidos. Madrid: Fondo de Cultura Económica. 
MORAIS, J. Mauro (2005) Crédito Bancário no Brasil: Participação das Pequenas Empresas e Condições de Acesso. CEPAL. Serie Desarrollo Productivo, num. 168.

MOREIRA, Maurício and PUGA, Fernando (2000) Como a Indústria Financia o seu Crescimento: um análise do Brasil pos-Plano Real. BNDES. Texto para Discussão, num. 84.

OIT (2007) Panorama Laboral 2006. Ginebra: OIT.

ORHANGAZI, Özgür (2007): Financialization and Capital Accumulation in the Non-Financial Corporate Sector: a Theoretical and Empirical Investigation of the U.S. Economy: 1973-2003. PERI. Working Paper num. 149.

PALLEY, Thomas I. (2007) Financialization: What it is and Why it Matters. The Center of Global Political Economy, University of Sussex. Working Paper num. 153.

PLIHON, Dominique (2004) Le nouvean capitalisme. Paris: La Decouverte.

SÁINZ, Pedro and CALCAGNO, Alfredo (2008) La Economía Brasileña ante el Plan Real y su Crisis. CEPAL. Series CEPAL, num. 99.

STOCKHAMMER, Engelbert (2007) Some Stylized facts on the Finance-Dominated Accumulation Regime. PERI. Working Paper num. 142.

TERRA, Maria C. T. (2003) "Credit Constraints in Brazilian Firms: Evidence from Panel Data". Revista Brasileira de Economia, 54(2): 443-464. 